\title{
QNREL
}
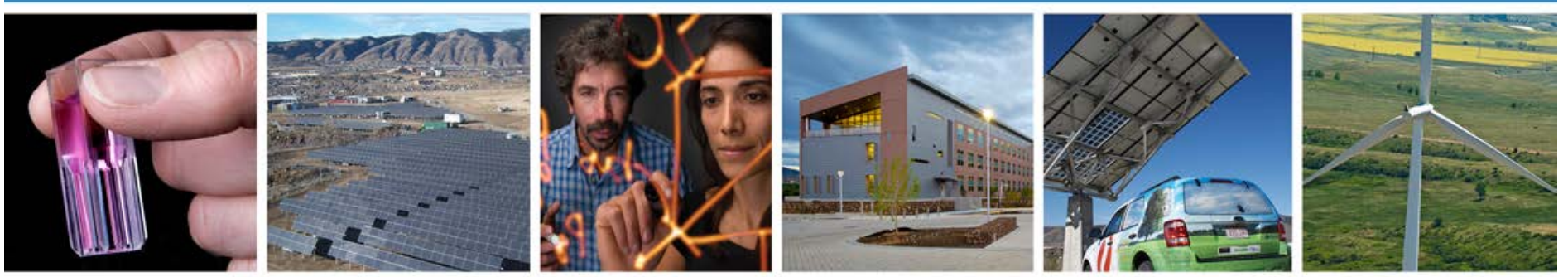

\section{Influence of Impurities in Module Packaging on Potential-Induced Degradation}

Peter Hacke, Stephen Glick, Steve Johnston, Robert Reedy, Joel Pankow, Kent Terwilliger, and Sarah Kurtz National Renewable Energy Laboratory

Presented at the 22nd Workshop on Crystalline Silicon Solar Cells \& Modules: Materials and Processes Vail, Colorado July 22-25, 2012

NREL is a national laboratory of the U.S. Department of Energy, Office of Energy Efficiency \& Renewable Energy, operated by the Alliance for Sustainable Energy, LLC.

Technical Report

NREL/TP-5200-56301

September 2012 


\section{Influence of Impurities in Module Packaging on Potential-Induced Degradation}

Peter Hacke, Stephen Glick, Steve Johnston, Robert Reedy, Joel Pankow, Kent Terwilliger, and Sarah Kurtz National Renewable Energy Laboratory

Presented at the 22nd Workshop on Crystalline Silicon Solar Cells \& Modules: Materials and Processes

Vail, Colorado

July 22-25, 2012

Prepared under Task No. SS12.2520

National Renewable Energy Laboratory 15013 Denver West Parkway Golden, Colorado 80401 303-275-3000 • www.nrel.gov
NREL is a national laboratory of the U.S. Department of Energy, Office of Energy Efficiency \& Renewable Energy, operated by the Alliance for Sustainable Energy, LLC.

Technical Report

NREL/TP-5200-56301

September 2012

Contract No. DE-AC36-08G028308 


\section{NOTICE}

This report was prepared as an account of work sponsored by an agency of the United States government. Neither the United States government nor any agency thereof, nor any of their employees, makes any warranty, express or implied, or assumes any legal liability or responsibility for the accuracy, completeness, or usefulness of any information, apparatus, product, or process disclosed, or represents that its use would not infringe privately owned rights. Reference herein to any specific commercial product, process, or service by trade name, trademark, manufacturer, or otherwise does not necessarily constitute or imply its endorsement, recommendation, or favoring by the United States government or any agency thereof. The views and opinions of authors expressed herein do not necessarily state or reflect those of the United States government or any agency thereof.

Available electronically at http://www.osti.gov/bridge

Available for a processing fee to U.S. Department of Energy and its contractors, in paper, from:

U.S. Department of Energy

Office of Scientific and Technical Information

P.O. Box 62

Oak Ridge, TN 37831-0062

phone: 865.576 .8401

fax: 865.576 .5728

email: mailto:reports@adonis.osti.gov

Available for sale to the public, in paper, from:

U.S. Department of Commerce

National Technical Information Service

5285 Port Royal Road

Springfield, VA 22161

phone: 800.553 .6847

fax: 703.605.6900

email: orders@ntis.fedworld.gov

online ordering: http://www.ntis.gov/help/ordermethods.aspx

Cover Photos: (left to right) PIX 16416, PIX 17423, PIX 16560, PIX 17613, PIX 17436, PIX 17721

Printed on paper containing at least $50 \%$ wastepaper, including $10 \%$ post consumer waste. 


\begin{abstract}
Chemical compounds were added into crystalline silicon cell mini modules, including in the encapsulant, interfaces, and glass, to determine their effect on potential-induced degradation (PID). Fe, either in the glass or at the glass/encapsulant interface, was found to be correlated with increased PID, but the difference in module power loss was not statistically significant compared to controls. Additions of $\mathrm{Cu}, \mathrm{Cr}, \mathrm{Pb}, \mathrm{Sn}, \mathrm{Ag}$, and $\mathrm{Na}$ compounds to either the encapsulant or at the glass/encapsulant interface did not appear correlated with PID. Lock-in thermography on bare cells affected by PID removed from the mini modules show highly localized areas of junction breakdown, and SIMS analysis indicates localized impurities as well, though a spatial relation between the two was not established. Deposition of a conductive layer on the front surface of the cell, either with semitransparent Ta or Poly 3,4-ethylenedioxythiophene (PEDOT), eliminated PID when the cells were stressed at $-1000 \mathrm{~V}$ bias, $50^{\circ} \mathrm{C}$, with the glass face grounded for $140 \mathrm{~h}$.
\end{abstract}

\title{
Introduction
}

Potential-induced degradation (PID) occurs in some conventional p-type base crystalline silicon cell modules in negative voltage strings. It is believed to be associated with positive charge moving from the grounded module frame, along the front surface of the glass when damp, dirty, or wet, through the soda-lime glass and encapsulant to the cell [1-2]. Species from the glass such as sodium have been seen to accumulate at the cell front [1]. PID is mitigated by making the glass or encapsulant more resistive, or by generally increasing the resistive path from the active layer of the module to ground [1]. On the cell level, increasing the index of refraction of the silicon nitride antireflective coating has been reported to improve resistance to PID [3]. This was speculatively associated with an increase in conductivity or a change in trap states [4].

PID leads primarily to fill factor degradation, which can be modeled with increased second-diode pre-exponential and ideality factor and decreasing shunt resistance in a two-diode model [5]. A number of physical models have been proposed for PID. This includes a charge model, whereby the negatively biased cell attracts cations that interact with the silicon nitride, possibly creating dipoles in the silicon nitride dielectric and locally distorting the bands in the emitter. The second is an impurity model, whereby positive ions are attracted to the cell and the impurities themselves cause recombination in the junction. Third, positive charge may be accelerated by an electrical potential over silicon nitride causing lattice damage [6]. All these models involve charged species interacting with the cell. Use of a conductive layer over the antireflective coating of a cell connected to the cell base was proposed to mitigate 'polarization' in back-contact n-type cells [7]. In this study, we examine how additions of various species in the module package affect PID to gain understanding of the PID mechanisms in conventional p-type base silicon cells.

\section{Experiment}

A series of one-cell mini modules was constructed with multicrystalline Si cells, ethylene vinyl acetate (EVA), glass, and conventional polyester back sheets. Various chemical additions were made to induce or mitigate PID. 
First, saturated solutions of iron (II) chloride, copper acetate, chromium (II) chloride, lead acetate, tin (II) acetate, and silver acetate in ethanol were made. The solutions were placed in patches between the ethylene vinyl acetate and the front glass. The transition metal compounds of $\mathrm{Fe}, \mathrm{Cu}$, and $\mathrm{Cr}$ were placed in different areas over three one-cell mini modules, and the compounds of species found in solder alloys, $\mathrm{Sn}, \mathrm{Pb}$, and $\mathrm{Ag}$, were placed in different areas on three other one-cell mini modules. Transition metals were tested in view of their role as recombination centers in silicon in even small concentrations, while components of solder alloys were examined because they are typically found in abundance on soldered tabs in PV modules. Three mini modules without added impurities were made for comparison. A bias of $-1000 \mathrm{~V}$ was applied to the shorted module leads at $40^{\circ} \mathrm{C}, 35 \%$ relative humidity for $33 \mathrm{~h}$. Aluminum foil was pressed on the glass face to achieve grounding. Degradation in the stressed samples was estimated by measuring the leakage current at $0.5 \mathrm{~V}$ reverse bias (assumed to correspond to the shunt resistance of the cell). Thermography was carried out to determine any spatial relation between the added impurities and the PID.

Second, a designed experiment to determine the effects of iron and sodium in the glass was carried out. Module packages with varying glass type (Fe-containing and low-Fe) and EVA type (conventional and with 10\% sodium acetate added) were stress tested at $-1000 \mathrm{~V}, 120 \mathrm{~h}$, and $45^{\circ} \mathrm{C}$. The glass face was grounded using carbon-containing paste. Module degradation in these samples was evaluated using a Sinton Instruments Suns-Voc tester.

Third, lock-in thermography (LIT) to image and locate PID hot-spots and secondary ion mass spectroscopy (SIMS) to image impurities as a function of depth were performed on cells with mini modules encapsulated using a procedure to allow extraction of the cells [7]. These modules were stressed at $-1000 \mathrm{~V}, 50^{\circ} \mathrm{C}, 10 \%$ relative humidity for $168 \mathrm{~h}$ with $\mathrm{Al}$ foil grounding on the module face.

Finally, semi-transparent layers of Ta were applied by electron beam physical vapor deposition and PEDOT (Clevios PH1000) was applied by slot-die coating on the surfaces of cells, three with each material, to test the effectiveness of conductive layers to inhibit PID. Three controls without coatings were also prepared for comparison. These samples were stressed as those for LIT and SIMS (above), but for $140 \mathrm{~h}$. Module power degradation was evaluated using dark I-V measurements and the superposition principle [5].

\section{Results and Discussion}

Fig. 1 (top) shows the transition metal compounds of $\mathrm{Fe}, \mathrm{Cu}$, and $\mathrm{Cr}$ that were placed in different areas over the cells in mini modules, and Fig. 1 (bottom) shows those with $\mathrm{Sn}, \mathrm{Pb}$, and Ag. Thermography images obtained after the stress tests are superimposed to determine any spatial relation between the deposited impurities and junction failure by PID. There was no exact correspondence between regions covered by any of these impurities and junction failure, but hot spots were generated most frequently where iron (II) chloride solution was deposited.

Power loss of the modules containing ionic species of solder alloys, transition metals, and with no added impurities compared after $33 \mathrm{~h}$ of stress is given in Fig. 2. The modules containing the transition metals $\mathrm{Cu}, \mathrm{Cr}$, and $\mathrm{Fe}$ are found to have exhibited the greatest power loss, but not statistically significantly so. 

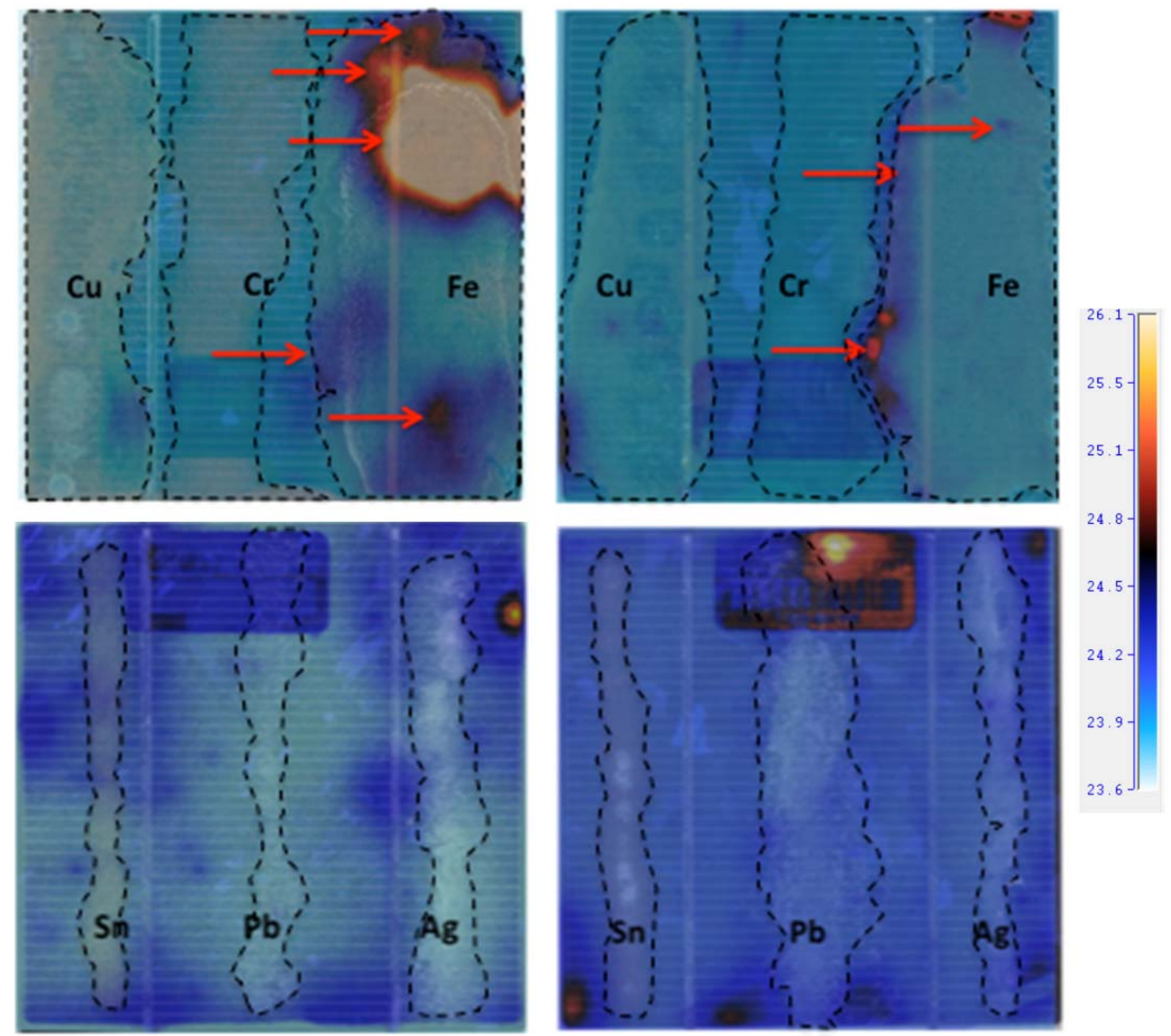

Figure 1. Optical images of four encapsulated cells with patches of $\mathrm{Cu}, \mathrm{Cr}$, $\mathrm{Fe}$ compounds (top) and $\mathrm{Pb}$, Sn, Ag compounds (bottom) superimposed with thermography images of cells in reverse bias obtained after inducing PID, showing spatial relations between added impurities and junction breakdown. The perimeters of the impurity patches are highlighted with dashed lines. Regions with the Fe compound added develop the most hot spots-red arrows point out some examples. Heating on the cell edges is believed to be from edge isolation failures. The temperature scale at the right is given in ${ }^{\circ} \mathrm{C}$.

Results of additional testing to evaluate the effects of Fe and $\mathrm{Na}$ that were carried out in a designed experiment are shown in Fig. 3. The results show that mini modules constructed with the Fe-containing glass degrade to a lower mean open-circuit voltage than those without, but statistically, we cannot confirm there is a difference with use of the Fe-containing glass. More work to define the role of Fe in degradation (if any) will be the subject of future work. Addition of Na to the EVA produced no change in the mean degradation compared to the samples without added Na under the stress regime we used. 
It must be considered that with additions of impurities, two variables are changed. Conductivity between the active layer (the cell) and ground is increased, and the introduced species itself has the potential to fundamentally cause PID. In these experiments, the two variables remain convoluted. Despite not seeing additional sodium introduced into the module via the EVA promoting PID, Na is believed to enable PID by providing conductivity through glass [1].

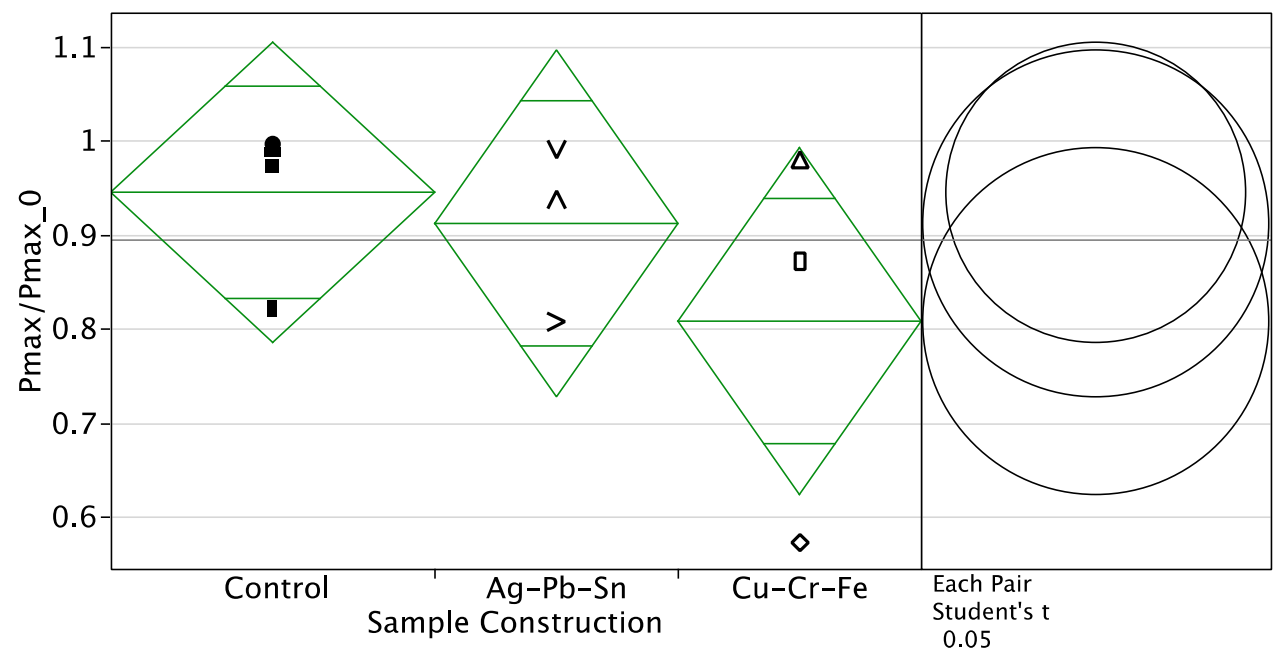

Figure 2. Degradation of mini modules containing intentionally included ionic impurities after PID stress testing. Student's $t$ rings show the $95 \%$ confidence interval of the means. It is seen that the mini modules with the Fe-containing glass exhibit greater degradation than the low-Fe glass group, but the sample set does not show statistically significant results.
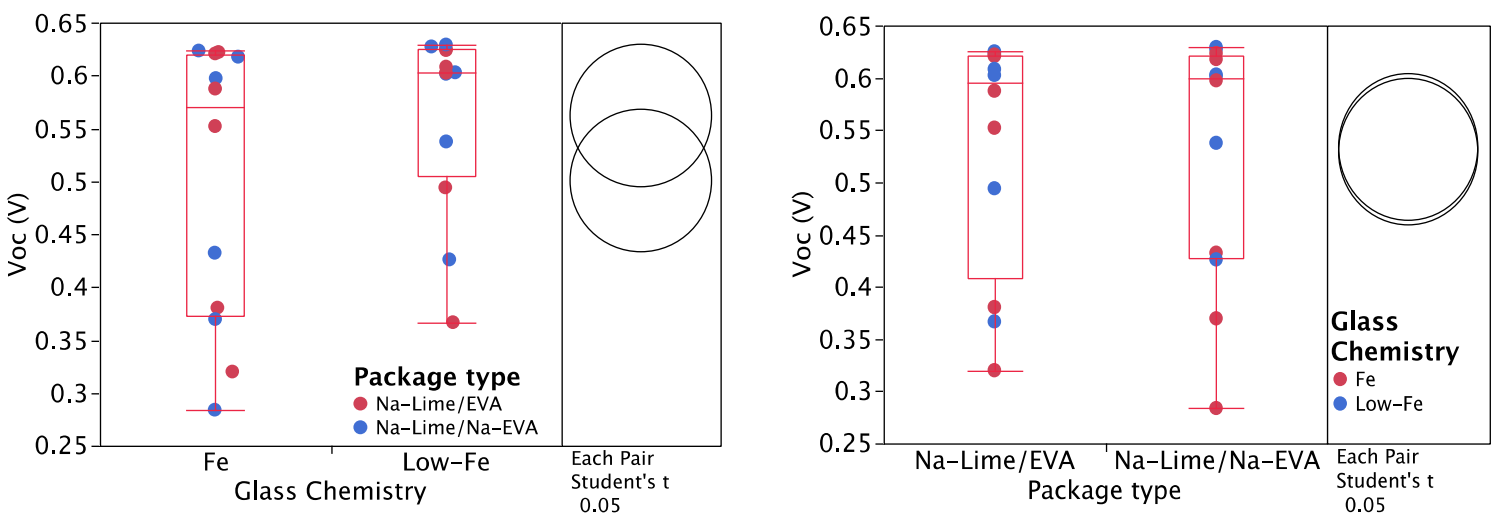

Figure 3. Designed experiment examining effects of glass chemistry (Fe-containing vs. low-Fe glass) and sodium in the encapsulant (conventional vs. Na-containing EVA). Fe-containing glass leads to more PID after stress testing, but not statistically significantly so (left). While sodium is known to cause ionic conduction enabling PID, additional $\mathrm{Na}$ added to the encapsulant did not increase PID as tested (right). Student's t rings show the $95 \%$ confidence interval of the means.

Relationships between PID junction failure and the location of impurities are sought to determine if and how impurities are involved in the junction breakdown. LIT imaging on an extracted cell 
from a mini module is shown in Fig. 4. The LIT images on the extracted degraded cell show PID-related hot spots at discrete points. SIMS analyses on this sample for Na are shown in Fig. 5 up to an estimated depth of $0.52 \mu \mathrm{m}$, a range at or beyond the junction depth. It is seen that impurities tend to be clustered rather than evenly distributed. While there is an interesting consistency between the localized nature of both the impurities and junction degradation by PID, the exact spatial relation remains to be determined. Such spatial relation between Na clusters near the silicon surface and failed junction locations has been previously shown with an electron beam-induced current scan, supporting a charge model leading to emitter inversion [9].
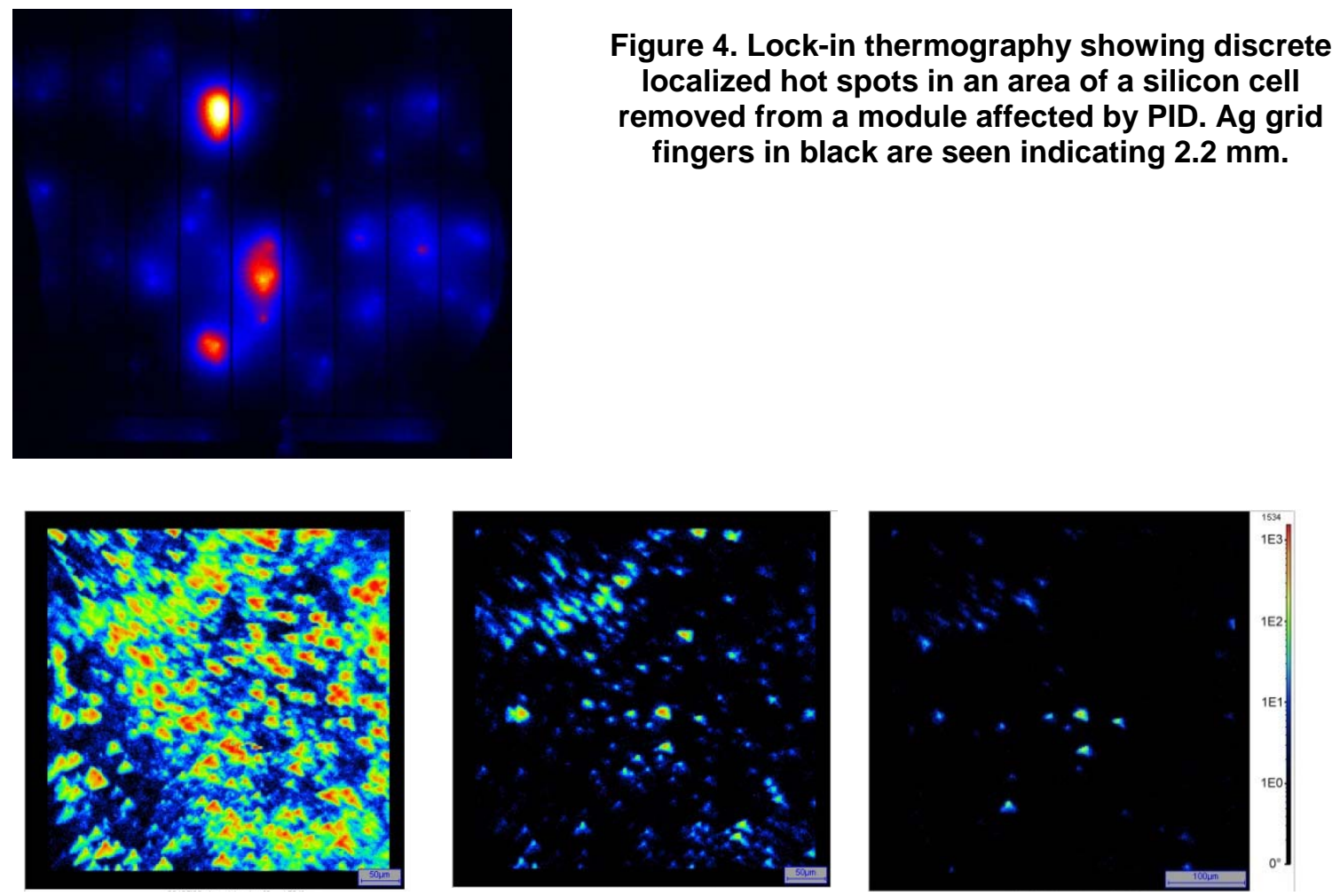

Figure 5. SIMS Na signal near the surface (left), $0.26 \mu \mathrm{m}$ depth (center), and $0.52 \mu \mathrm{m}$ depth (right) of a cell area degraded by PID. The color scale is given in counts. The images are $0.5 \mathrm{~mm} \times 0.5$ $\mathrm{mm}$.

PID power loss as a function of stress time is shown in Fig. 6 comparing mini modules with semitransparent coatings of Ta, PEDOT, and no coating on the cell. It is seen that use of the conductive coatings arrests PID. This finding supports the hypothesis that higher-index AR coatings inhibit PID because of the increase in conductivity, zeroing the electrical potential over the silicon nitride layer as was achieved here using the conductive coatings that connect the top silicon nitride surface to the Si below via the grid fingers. This result is consistent with all three mechanistic PID models introduced. The driving force for ions to move through the silicon nitride toward the silicon is eliminated. Also, positive ions at the silicon nitride front may be chemically reduced with the supply of electrons provided by the negative potential applied to the cell, stopping their advancement toward the silicon. 


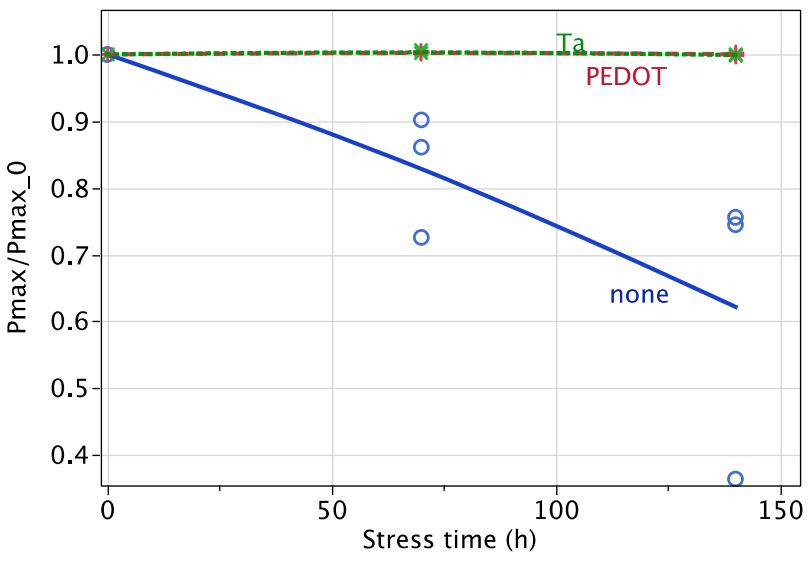

Figure 6. Power loss vs. time of mini modules made with cells with conductive coatings (Ta, PEDOT) and without coating. There are three samples in each experimental split. The conductive coatings are seen to mitigate the PID.

\section{Summary and Conclusions}

Addition of iron (II) chloride to the module package and use of iron-containing glass appeared to promote PID, but a statistically significant conclusion on the effect of iron on power loss by PID could not be drawn. Placing $\mathrm{Na}, \mathrm{Cr}, \mathrm{Cu}, \mathrm{Ag}, \mathrm{Pb}$, and $\mathrm{Sn}$ compounds in the module package were not found to promote PID when compared to samples without these added compounds that were similarly stressed. Highly localized hot spots and elevated concentration of ionic species, Na in particular, was seen in areas degraded by PID, but a spatial relation between the two was not clarified. Conductive coatings deposited on cell surfaces were found to arrest PID; they are believed to eliminate the electrical potential over the silicon nitride, removing the driving force for ions to move beyond the silicon nitride front further toward the silicon.

\section{Acknowledgements}

The authors thank Greg Perrin for stress testing equipment and support, and Anna Duda and Scott Hammond for applying cell coatings. This work was supported by the U.S. Department of Energy under Contract No. DE-AC36-08-GO28308 with the National Renewable Energy Laboratory.

\section{References}

[1] P. Hacke et al., "Characterization of Multicrystalline Silicon Modules with System Bias Voltage Applied in Damp Heat,” 25 ${ }^{\text {th }}$ EU PVSEC, Valencia, Spain, 2010, pp. 3760-3765.

[2] P. Hacke et al., "System voltage potential-induced degradation mechanisms in PV modules and methods for test,” $37^{\text {th }}$ IEEE PVSC, Seattle, 2011, pp. 814-820.

[3] S. Pingel et al., "Potential Induced Degradation of Solar Cells and Panels," $35^{\text {th }}$ IEEE PVSC, Honolulu, 2010, pp. 2817-2822.

[4] S. Pingel, "Potential Induced Degradation (PID)," Proceedings of the Fraunhofer ISE: PV Module Reliability Workshop, Berlin, April 5-6, 2011. 
[5] P. Hacke et al., "Testing and Analysis for Lifetime Prediction of Crystalline Silicon PV Modules Undergoing Degradation by System Voltage Stress," $38^{\text {th }}$ IEEE PVSC, Austin, 2011, pp. 814-820.

[6] P. Hacke et al., "Potential-Induced Degradation and Failure of Modules by System Voltage Stress," Proceedings of the 21st Workshop on Crystalline Silicon Solar Cells \& Modules: Materials and Processes, Breckenridge, 2011.

[7] R. M. Swanson et al., "Preventing harmful polarization of solar cells," U.S. Patent 7554031, issued June 30, 2009.

[8] S. Koch et al., "Polarization effects and tests for crystalline silicon cells," $26^{\text {th }}$ EU PVSEC, 2011, Hamburg, pp. 17261731.

[9] J. Bauer et al., "On the mechanism of potential-induced degradation in crystalline silicon solar cells," Phys. Status Solidi RRL, 2012, 1-3, in print. 